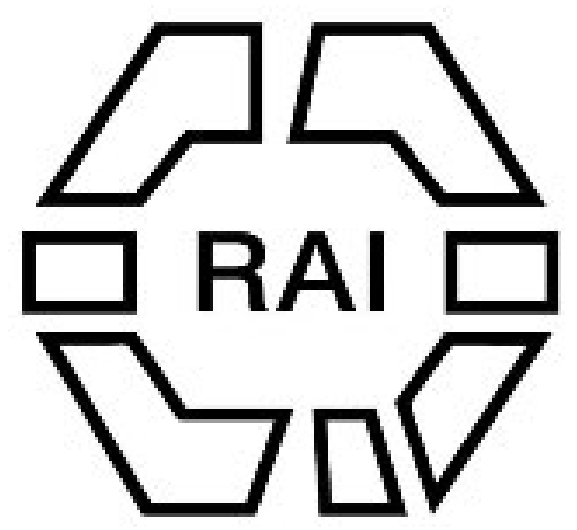

On Certain Points Concerning the Origin and Relations of the Basque Race.

Author(s): W. Webster

Source: The Tournal of the Anthropological Institute of Great Britain and Ireland, Vol. 2 (1873), pp. 150-159

Published by: Royal Anthropological Institute of Great Britain and Ireland

Stable URL: http://www.jstor.org/stable/2841157

Accessed: 14/06/2014 09:25

Your use of the JSTOR archive indicates your acceptance of the Terms \& Conditions of Use, available at http://www.jstor.org/page/info/about/policies/terms.jsp

JSTOR is a not-for-profit service that helps scholars, researchers, and students discover, use, and build upon a wide range of content in a trusted digital archive. We use information technology and tools to increase productivity and facilitate new forms of scholarship. For more information about JSTOR, please contact support@jstor.org. 
way confirmed in its genetic importance, is the fact that in the smallest embryos the brain is long, narrow, and much folded, and consequently so is the cranium itself, which may be especially perceived in the posterior and superior part of its vault, somewhat like the keeling of the dorsal spine; a form which, not expanding at the proper time in a normal manner and measure, especially at the superior posterior region of the cerebral hemispheres, may thus perpetuate itself and produce scaphocephaly. I perceive clearly that this mode of its genesis will probably not appear to be well contrived; but not valuing the suppositions of one single and common centre of ossification common to the two parietals, nor that of the precocious synostosis of the sagittal suture, I have not known how to find a better."

These are mainly fresh views of the causes of scaphocephalism, which we have thought it desirable to state as nearly as may be in their author's own words. He adds that, if they be erroneous, he shall be grateful to have them corrected.

\section{On Certain Points concerning the ORigin and Relations of the Basque Race. By the Rev. W. Webster.}

DURING the last two years, a phrase has cropped up in treating of English history, not, indeed, unknown before, but hardly seriously maintained-viz., "Our Iberian forefathers," meaning by Iberian a race of which the Basques are the presumed modern representatives. This phrase, I think, needs careful examination. The three chief classes of evidence for the descent of peoples are-1, Historical; 2, Philological; 3, Anthropological.

The Iberian descent of the modern English, Irish, and Welsh from the Basques is said to be through the Kelts, and through that particular section of them which has been denominated the Black Kelts. I am not aware that the least historical or other evidence has been brought forward that this division of Kelts into black and white marks a real difference of race. But the theory has been extensively adopted, and has found its latest expression in the assertion of an anonymous writer in the Guardian newspaper, that "the Bretons and Basques are the same people."

The problem we have to examine, then, is whether the black Kelts - whether of England, Ireland, Wales, or Brittany - are identical with, or descended from, the Basques. Some colour may be given to the theory, in the minds of those who can accept it, by the dictum of Pliny, that Aquitania was formerly called Aremorica- "Aquitania, Aremorica antea dicta." Still more support may be gained from the words of Tacitus about the Silures, 
a people of South Wales ("Agricola," cap. xi) : "Silurum colorati vultus, torti plerumque crines et posita contra Hispania, Iberos veteres trajecisse, easque sedes occupasse, fidem faciunt." Certainly "torti plerumque crines" is not true of the Basques of the present day; and we may observe that in the geography of Tacitus, and of the Latin writers generally, the South-West Coasts of England and the North-West Coasts of Spain approached each other much more nearly than they really do.

1. Let us examine some of the earliest historical evidence. There is little doubt, from various indications, that the whole of Western Europe was in præ-historic times inhabited by tribes of Turanian race. That of these the traces had mostly disappeared before the era of history. That an exception occurs with regard to the Iberi of Spain, or whoever that people were who gave Basque (Escuara) names to the cities, rivers, mountains, in Bætica, and in that part of Spain enclosed between the Idubeda mountains and the Pyrenees. By the same topographical evidence, we find the same Escuara-speaking race occupying the northern slope of the Pyrenees as far north as the parallel of the Adour; but we have no evidence of their advance further to the north. This Iberian population of Spain was almost cleft in two by another set of tribes, called by all ancient authors, the KeltIberi. They seem to have stretched eastward from Lusitania, and to have occupied the whole of the central plateau of Spain, with the exceptions above denoted. In the north-west cornerGallicia and the Asturias-they were mingled with more purely Keltic tribes; and small isolated portions of Keltic tribes are said to have been found in places throughout the Peninsula.

These Kelt-Iberian tribes are said by all authors to have been a mixed race of Kelts and Iberians. The Iberians were, it seems, the older inhabitants. The Kelt-Iberians are described as differing greatly from the more purely Keltic tribes, and consequently we may infer that there was a greater and nore marked difference still between the Kelts and the Iberians. Contemporaneous with these populations in Spain, we find pure Keltic (Gallic and Belgic) tribes inhabiting Gaul from the Garonne to the Rhine; only the frontier tribes of the Belga seem to have already received a certain admixture of Teutonic blood. In Britain, the scanty notices give tribes analogous to those of the opposite coast of Gaul, but in a ruder state of civilisation. As soon as we have any definite accounts of them, the Iberian tribes are apparently in a higher state of civilization even than the Kelts of Gaul. Whether we follow the march of Hannibal from the Ebro to the Rhone, or of Crassus from the north into Aquitania, we arrive at the same result; the purely Keltic tribes are more barbarous than the Kelt-Iherian, or Iherian of the South. 
Now, the question meets us, from what direction did the Kelts come into Spain? What were the previous movements of the Keltic race as far as we can trace them? The earliest contemporaneous notices of the Kelts find them already established in the extreme west of Europe, and in the Spanish Peninsula (Herodotus); and as far as we can previously trace them, they seem to have traversed the centre of Europe, pressed forward by Scythic and Germanic tribes from the east and north. Thus they would enter Spain by the north, and apparently by the western end of the Pyrenees, as they spread down the northern and west coasts, and then mingled with the Iberi, and so formed the large Kelt-Iberian population of Western and Central Spain. All descriptions of the Kelt-Iberi mark them as definitely established in Spain; and so thorough a fusion of the two peoples must have been the work of a considerable lapse of time. And we ask what evidence there is that, after this settlement, any large body of them moved back on their course towards the north, or found their way to Britain? They did not go by land, for Cæesar clearly establishes the identity of the Belgic tribes of Britain and their opposite neighbours, and remarks the difference between these Belgic tribes and those of Gallia proper and Aquitania. The Gauls, too, were not a people to allow any free passage to Keltiberians from Spain. (Cf. Livy, xxi, cap. 20.)

Did they, then, reach Britain by sea? This seems to us most improbable. It is true that the Basques are fine sailors, but the Kelts are not remarkable as seamen; and I should imagine that there are few coasts in the world less tempting as a startingpoint for a voyage to the north than the north-western coast of Spain in the teeth of the prevailing N.W. winds. There may have been Iberian or Kelt-Iberian sailors in those early (Phœnician, or Carthaginian?) ships which traded with the Cassiterides. There may have even been some kind of factories on the coast, but not, I think, in sufficient numbers to influence the population. They were, I take it, like the early Greek factories in the Crimea and on the Sea of Asoph, and of no more influence on the surrounding population. We conclude from our historical review that, though undoubtedly there were Kelts in Spain and Aquitania, both pure and mingled with Iberians, there is no historical evidence that they ever migrated thence to the north or north-west, either by sea or land.

2. Philological evidence. Professor Huxley has stated "that the Basque language is the despair of philologists." "Indignor quandoque bonus dormitat Homerus." If Professor Huxley had waded through some of the weary tomes written on the Basque language before the era of modern comparative philology, 
and had afterwards looked into the more recent works of Charency, Inchauspé, Prince Napoleon, Van Eyss, Blarlé, etc., he would have declared the very opposite-viz., that one of the greatest triumphs of modern philology is to have put an end to that dark and dreary chaos, and to have introduced order and light therein. But worse; when Homer nods, his imitators often not only sleep, but dream. Just as the dictum of "our Iberian forefathers" led one too zealous follower into the assertion that Basques and Bretons are the same people; so, in a pamphlet entitled "The Basque Problem Solved," another disciple has deduced the Keltic languages directly from the Basque, with what success may be judged by the fact that in the example on which the greatest stress is laid, the postfixed plural article " ac" is treated as a radical of the word to which it is attached. The Basque language has, indeed, great powers of assimilation. It freely takes the vocabularies of other tongues, and inserts them, like bricks, into its own structure; but always according to its own peculiar architectural laws. Thus, in the Basque vocabulary, you may find examples of the languages of almost every race with whom the Basques have come in contact-Kelts, Phœnicians, Latins, Spanish, Gascon, French, etc. This will be seen by a glance at any modern Basque vocabulary. But the language itself belongs to none of these. In structure and grammar, it differs widely from them all. It is clearly agglutinative, and belongs to the great Turanian class of languages, not to the inflexional or Aryan. This, I believe, is now acknowledged by every competent student of the Basque. Max Müller has even declared the Basque to be one of the best representatives of the Turanian type. But with which particular group of Turanian dialects it has most affinity, whether with the Uralian or Finnic, or with the North American Indian, is still a question for future philologists. The Keltic dialects are clearly Aryan. There are, then, no philological grounds for assigning to the Basques the parentage of the Kelts, black or fair.

3. Are there, then, any anthrropological grounds for this assertion? The peculiar characteristics of the black Kelts are, as well as I can remember, a shorter stature than the fairer Kelts, darker hair, eyes, and complexion, a lower facial angle, and a tendency to prognathism in the jaw. Now the characteristics of the Basques are a wonderfully upright carriage, with what the French call " une taille élancée "” hair, eyes, and complexion fairer than their neighbours; a good facial angle, with a jaw decidedly not prognathous, sometimes with a marked opposite tendency.

It is unfortunate that nearly all the scientific observations made on the physical qualities of the Basques have been taken VOI. II. 
on or near the coast, where the population is necessarily more mixed, and the locality is most unpropitious to the purity of the race. Thus, at St. Jean de Luz and the vicinity, the neighbourhood of the sea, the lowness of the near mountains, the admixture which has now been going on for centuries with Spaniards, French, Gascons, and lately with gipsy blood (the Cascarrotas), must have all tended to darken the original tint. Yet even there, M. Argelliés, out of forty-seven examples, finds twenty-five examples of brown, and twenty-two of blue, green, or grey eyes. In the interior, and especially in La Soule, we are sure the proportion would be very different. There the fairness of the population and the prevalence of light hair and eyes strike every observer. Every authority, whatever be his special theory, admits that there are fair Basques to be found among the purest types of the race at the present day. Men like Arthur Young and Sir William Napier, who have no scientific theory to support, call them a fair race, the former even comparing them to the Scotch highlanders in this respect.

But it may be answered, these Basques only appear fair by contrast; they are still dark enough to stain the fairer Keltic blood. This, too, is easily decided. The Gascon population in the Pyrenees has decidedly a large element of Keltic blood; yet they are darker than the Basques. We can observe, too, the effect on this race when it comes in contact with the Basques. Take the population of the Vallée d'Aspe as a crucial instance. The mountains there are higher than in the Pays Basque, which should render the population fairer. But in the upper part of the valley, about Urdos, we find a dark Spanish type; in the lower part, where the valley spreads out into the great southern plain, at and below Oloron, we have the ordinary Gascon or Béarnais type; but half-way down the valley, in the basin of Bédous, and especially in the villages Athas, Lées, and Osse, which are divided from the Basques merely by a mountain ridge, there we find fair complexion, eyes, and hair, quite a characteristic, and the boys and girls like those of an English village. In the same way, on approaching Mauléon from Sauveterre, we have always been struck with the blue eyes and fair hair. At Biarritz (on the confines of the Basques), great caution is necessary, as not only a great part of the population is not indigenous, but Morisco* blood is in the veins of some of the oldest families; yet in two or three of the decidedly Biarrot families we find blue-grey eyes and light hair. These facts we

* The Dalbarades and Silhouettés are descended from Moriscos. Cf. Fr. Michel's " Histoire des Race Maudites". The Boulanguets, Larrodets, and Peilhos, are fair. These are large families, with their connections, comprising a good part of the Biarrot population. 
have heard accounted for by explanations which appear to us wholly inadequate. E.g., at Osse the fairness has been attributed to the Cagots; in La Soule, to the presence of the English garrison at Mauléon, at the time of the English domination in the twelfth and fourteen centuries. But it is most doubtful if the Cagots were really a separate race. The English garrisons remained longer in the Argelez valley at Lourdes, Beaucens, and Luz; yet the same phenomenon is not exhibited there. Besides, if the Basques were really a dark race, the very small influx of English fair bloou (for these socalled English garrisons were composed mostly of Gascon subjects of England) would long ere this have been absorbed into the prevailing tint. And not only in the colour of hair and eyes do the Basques show signs of being in part, at least, a fair race. Dark hair and eyes are often conjoined with a florid complexion in the men, and with a blooming complexion of red and white in the fair sex, very different from the mât and even tint which marks a really dark race. This fact has often been reniarked by writers on the Pyrenees-e.g., by Chausenque, who brings it forward as the peculiar beauty of the Basque women: "I.e sang y est beau; les Basquaises se distinguent même de leurs voisines du Béarn, par une grande fraicheur, des traits reguliers," etc. The parts of the skin usually covered show often great fairness, even when the face and hands are very sunburnt. The observer must be on his guard against taking a merely sun-burnt complexion for a really dark one. The difference will be seen at the change of the seasons. If the Basques had been originally a dark people, whence could they have obtained their present fairness? The infusion of Cagots and English blood is manifestly inadequate to account for it. Their locality would tend to darken an originally fair people, and the tendency of the whole population of Gaul, and perhaps of Germany likewise, has been for some centuries to become darker instead of lighter, whatever cause we may assign it to. It is not the mountain home of the Basques which makes them fair, for the men of Béarn and Arriège dwell in higher mountains, yet are much darker. The comparative fairness of the Basques can, we think, belong only to the race.

These three points of history, philology, and anthropology, contain, we think, the only decisive evidence as to race ; but there are certain subsidiary facts from which inferences of more or less value may be drawn.

The religion of the ancient Kelts is well marked with Druidism; and its remains of burial tumuli, menhirs, dolmen, etc., are sufficiently patent. Many of such remains are found near, but none, as far as we are aware, in the Pays Basque. On M 2 
the Landes d'Ossun, near Lourdes, the tumuli stand thick. In the Vallée d'Aspe, Keltic remains are still semi-worshipped, and Keltic names appear. But of the religion of the ancient Basques no sign remains. Some Roman altars, with barbarian epithets of Roman deities, or with Latin epithets of barbarian deities, and the remains of Roman temples, have been found in the Pays Basque, but nothing by which we can certainly trace what the Basque deities originally were. Chaho's descriptions, so deeply tinged with his peculiar metaphysical ideas, cannot be accepted as evidence. They are the visions of an enthusiast. The early Christian missionaries, St. Amand, and the legend of St. Leo of Bayonne, both speak of idols, but what these were we know not. But a great difference appears in the reception of Christianity. The Kelt, even in Britain, seems to have been eminently susceptible of it; but, though a Roman road runs through the heart of their country, the Basques were but lately and very gradually Christianised. They now cling with firmness to Roman Catholicism, and are a church-going and religious people, not given to excess or extravagance. Except La Madeleine (the site of a Roman temple), at Tardets, in, but on the borders of, the Pays Basque, we know of no place of pilgrimage or thaumaturgic shrine in the country, whereas in Béarn and Gascony they abound. Roncesvalles is clearly a Spanish foundation.

The Kelts, as Mommsen observes, are fond of cities. The Basques are remarkably the contrary. They delight in scattered habitations. Many of the Basque villages have nothing that can be called a street. They emigrate to South rather than to North America. The loneliness of Pampas life seems rather to attract than to repel them. "In forty-eight hours after their arrival," said the French chargé d'affaires to me, at Montevideo, "you will not find a Basque in the town." And in those countries, the Basque is never confounded with the Spaniard or the Frenchman. The brand of race is deeper in him than the marks of nationality. Men speak there of Basque, Spaniards and French as most distinct.

Their mental power is said by themselves to be analogous to what is indicated by the form of the skull. They are of quick, precocious intelligence, rather than of great intellectual power. They are singularly polite and courteous to strangers in the remoter districts. As compared with the Gascons, they are truthful and honest, very tenacious, and obstinate; extremely courageous in their own country and in their own quarrel; they do not flaunt their bravery, nor do they seem inordinately ambitious of military fame. Exceedingly fond of athletic games, excepting perhaps ourselves, there is no people in Europe which pursues them with such ardour. There is no village-scarcely 
a hamlet of a few scattered houses-which does not possess its "jeu de Paume ;" and the "jeu de Pelote" is a splendid rival to cricket. The language easily rhymes; and improvisation is common. Allegory and a certain manly tone are the characteristics of their poetry. The pastorales, or open-air dramas, now performed in La Soule alone, deserve much more attention than has been given them. The sexes are never mingled in these representations. The plots seem to be invariably drawn from the lives of saints (and these are acted by females alone), or from a traditional memory of the Chansons de Gestes; but the manner of acting and the "mise en scène" is not exclusively mediæval, but often recalls classical times. The dancing chorus of Satans (the native term), which enters into every piece, is most curious.

I hardly know whether it is worth while to pursue these remarks further, though there is still much of interest to notice. Perhaps one of the strangest facts in the language is that the week apparently consists of three days only. But I must stop. The Basques are like the Kelts in one thing-their passion for gaming; and the Highland fling may be compared with the Saut Basque. If the British exclamation, "By Jingo!" can be traced to the British Kelt, it may prove a powerful link between the two races (though some might say even that was introduced from the time of the English domination), for the Basque name of the Deity is certainly "Jinkoa, Yunkua, yaincoa, jaincoa ;" and if we could but make out the etymology, the "makila," the loaded medlar bludgeon, wielded with effect by all Basques, may be the grandfather of the Irish "shellala," with which proofs of my strict impartiality I bring these remarks to an end.

\section{Discussion.}

Dr. Charnock was glad some one had had the courage to attack the heresy as to "Our Iberian Ancestors." There is really no evidence to support the theory, except so far as might relate (which it did not profess to do) to the Spanish element in Galway. As the authors of the paper show, the evidence is the other way. The most important fact relates to race-colour. Compared with their neighbours, the Basques are, without doubt, fair in countenance, hair, etc., and, as suggested, if they are so now, they were probably still fairer in ancient times. During the last two thousand years not only the peoples of France and Germany, but also (where possible) the inhabitants of the rest of Europe had been getting darker; but if the Iberian theory is true, the Basques must have become fairer. Messrs. Webster suggested that some colour may have been given to the theory from Pliny's dictum that Aquitania was formerly called Aremorica. This might or might not be the case. In ancient times nearly the whole of Normandy, as well as Bretagne, was known under the name of Armorica; and, from being buunded by the Lrg, 
Lig, Ligr, or Loire, this district is in some maps called Lugdunensis. The name Armorica, like that of Pomorania, means simply, "upon the sea." It is probable also that all the country between the Loire and the Pyrenees, which in ancient maps is designated Aquitania, may, for the like reason, have been called Armorica or Aremorica. Aquitania would appear to be a sort of dog-Latin term to express the same thing. It has been asserted that the Basques and Bretons are one and the same people, and that the Keltic languages are derived from the Basque. We have also been told that the Caucasus is the cradle of the human race. We might dismiss fifty modern theories of this sort with "Cras credemus, hodie nil." The authors of the paper are of opinion that the whole of Western Europe (except the country occupied by the Iberi) had, in pre-historic times, been inhabited by socalled Turanian peoples; but no authority had been given for such assertion. With respect to the Basques, they may or not be Turanians. Their language is agglutinative, their skull-form dolichocephalic. According to Humboldt (Prüfung der Untersch. d. Urbewohner Hispaniens), the Iberi anciently occupied the whole of the Peninsula; and he asserted that Basque names are found in every part of the country. He (Dr. Charnock) did not believe there is any ground for this assertion, or that the Basques ever occupied a much more extended area than they do at the present day. There might be some doubt as to Bøtica. The so-called Basque names which occur there are mostly compounded of ippo, ast, and ur, uri, or illi. Now ippo (which Humboldt derives from $\iota \pi \pi o s$ ) is really a Phœnician word, signifying "beautiful," as the Bœtic Irippo, "beautiful city". It is, in fact, the same with the Hebrew Japho, or Joppa. "Ast" is probably a Greek vocable; whilst uri, illi may be either from the Basque iria, uria, a city, town, or, from its root, Phœnician ir. But Humboldt is not content with this; he shows the migrations of the Iberi by local names in Thrace, Italy, Sicily, Corsica, and Sardinia. He (Dr. Charnock) did not believe a word of this; the names given being mostly of Greek, Latin, Phœnician, or Keltic origin. Apropos of three of these names mentioned by Humboldt or in the present paper. The appellation Orvieto is doubtless considered to be Basque, because of the first syllable, which resembles uria, a city; and Urbinum is rendered "place of two waters," from urá, water. Ignoring history, it is impossible to arrive at the meaning of geographical terms. The name Orvieto was originally Urbs Vetus, whilst Urbino was formerly Urbisbina. Humboldt compares the Italian river Astura (Festus Stura) with several river names in Iberia, and he renders it rockwater (ast-urá for acha-or aitz-aurá). Astura is etymologically the same word as the classic Ister, the river Oyster (whence Oystermouth) in Wales, the two rivers Stura in Italy, the Steyer, which gives name to Styria, the Styr in Gallicia and Russia, and the Stor, Stör, Stour, in Denmark, Germany, and England, which are all derived from the Keltic dwr, dour, = water, prefixed by a sibilant. Professur Huxley had stated that the Basque language is the despair of philologists, and if we might judge from what had been written on 
the subject, it no doubt is so. Larramendi says it is the most pleasing, the most harmonious, the most perfect, the most rich, the most copious, and the most ancient of languages. According to some authors, it was the language of Paradise and of the angels, and all other languages are derived from it. Basque authors assert that it is derived from the Phœnician. Dr. Webster tells us it is one of the purest remains of the Keltic. It nevertheless contains very few words from the Phœnician, and probably not half a dozen from the Keltic languages. Another writer traces it to the ancient Mauric, but none of the words appear to bear any resemblance to the Amazirgh, or to any of the North African languages. According to Borrow, it contains a great many Tatar words, and its surface is literally strewn with Sanskrit words. There is, however, probably not a Tatar word in the vocabulary, nor a single Sanskrit word that has not found its way into it except through the Greek, Latin, and derivative languages. The difficulty of acquiring the language led to the story that the devil studied Basque for seven years, and only learnt three words. The grammar agrees to some extent with the Tatar and Finnic-Tatar, and also with some of the American languages. At least one-half of the vocabulary is derived direct from Greek and Latin. There are quite three thousand words from the Spanish and Arabic, and some few from the Phœnician, the Keltic, the Gothic, and other European languages. This would reduce the native words to about twelve or thirteen thousand, which are probably built up from one thousand to twelve hundred words; but whence these root words are derived it is impossible to say.

\section{Mann, its Names and their Origins. By J. M. JefFcott, High Bailiff of Castletown.}

The island of Mann has a central and isolated position in the Irish Sea, and has an area of about 145,325 acres. Many names have been given to this island. From Cæasar's account of the position of Mona, it has been inferred that Mann is the island to which he gave that name. The Mona of Tacitus is undoubtedly Anglesey, but what he wrote about it has, by Polydore Virgil, Hector Boetius, and other writers, been erroneously applied to Mann. After mentioning the passage from Treland into Britain, Cæsar says :- "In hoc medio cursu est insula quæ appellatur Mona; complures præterea minores objectæ insulæ existimantur." ("In the middle of this voyage is an island which is called Mona; many smaller islands besides are supposed to lie there.") If Mann be the island here referred to, the description is not so applicable as it at first sight seems. Cæsar, probably, intended to describe the position of Mona, as that position would appear during a voyage from the eastern shores 